\title{
Drinking water quality and water risk assessment in the university of science and technology of southern Philippines
}

\author{
Rosalinda Ilogon 1, 2, Janssen Blaise U. Jumau-as 1,2, Daizyree A. Baran 1, 3, Aileen A. Bayron 1, 4, Aurora Estrella \\ Tenchavez $^{1}$, Celestina E. Casundo ${ }^{1}$, Van Ryan Kristopher R. Galarpe ${ }^{5}$ *
}

\section{${ }^{1}$ Department of Environmental Science \& Technology, University of Science \& Technology of Southern Philippines, Cagayan de} Oro, Philippines

${ }^{2}$ Department of Environment and Natural Resources-Environmental Management Bureau Laboratory 10, Cagayan de Oro, Philippines

${ }^{3}$ DOST-Philippine Atmospheric Geophysical and Astronomical Services Association (PAG-ASA), El Salvador, Philippines ${ }^{4}$ Cagayan de Oro Water District (COWD), Cagayan de Oro, Philippines

${ }^{5}$ Department of Environmental Science and Technology, College of Science and Mathematics, University of Science and Technology of Southern Philippines, Cagayan de Oro, Philippines

\section{ARTICLE INFO}

\section{Article history:}

Received 26 May 2017

Received in revised form

3 September 2017

Accepted 12 September 2017

\section{Keywords:}

Water quality

Risk assessment

Heavy metals

\begin{abstract}
A B S T R A C T
The study evaluated the quality of drinking water sources in the University of Science and Technology of Southern Philippines (USTP). The main objective was to determine drinking water quality of different water sources in the university. Six sampling stations were identified which included faucets and water fountains in the different departments of the university, namely engineering, science center, education, and information technology. Physicochemical analyses included pH, temperature, dissolved oxygen (DO), total dissolved solids (TDS), alkalinity, lead (Pb), and cadmium (Cd). Sampling periods commenced on July to September 2014. Overall the university's drinking water sources were within allowable limits set by the Philippine National Standard for Drinking Water (PNSDW). However, Pb and Cd concentrations were beyond the permissible limits. Risk assessments for both metals showed potential contamination. The results of the study is preliminary by nature and further monitoring be implemented.
\end{abstract}

(C) 2017 The Authors. Published by IASE. This is an open access article under the CC BY-NC-ND license (http://creativecommons.org/licenses/by-nc-nd/4.0/).

delay development for children (US EPA, 2014), stillbirths, deformities, and brain damages (Hernberg, 2000). Thus, any sources of water contamination must be monitored to mitigate the risk.

Several cases of water contamination in the Philippines were identified mainly associated to coliform and heavy metals. Studies revealed contamination of groundwater resources in landfills (Galarpe and Parilla, 2014; Su, 2008), coliform in river water (Bensig et al., 2014) and coastal waters (Lago, 2013). Consequently, a need to monitor drinking water resources is timely to secure public health.

The study was conducted to determine the quality of the drinking water in the University of Science and Technology of Southern Philippines (USTP). Samples from different sources were evaluated in terms of its physicochemical properties and the possible $\mathrm{Pb}$ and $\mathrm{Cd}$ contamination. It was aimed to evaluate the quality of drinking water sources in the university by comparing it to available water quality standards and extrapolating potential 
risk estimates through available risk assessment methodologies.

\section{Materials and methods}

\subsection{Study area}

Six water samples were obtained from different locations and time in USTP. Samples were collected in the morning and afternoon from the different faucets and water fountains in Engineering, Science Center, Education and Information Technology departments. The samples collected were stored in a clean 100-mL glass bottles and transported to the laboratory. All analyses were carried in triplicates.

\subsection{Physico-chemical analysis}

Each parameter were measured using the different meters; pH (Model CD-221, Lutron Enterprises Inc., Taipei, Taiwan), DO meter (Model D0-5519, Lutron Enterpises Inc., Taipei, Taiwan), Electric Conductivity (Model CD-4322, Lutron Enterpises Inc., Taipei, Taiwan), Turbidity (Model TU-2016, Lutron Enterpises Inc., Taipei, Taiwan), Hand-held Refractometer (Model Master S-28M, Atago Co., LTD, Japan). Alkalinity was carried out by a titrimetric method (APHA, 1998).

\subsection{Heavy metals analysis}

Determination of the concentrations of lead and cadmium in each water sample was done using Analytik jena novAA 300, Flame - Atomic Absorption Spectroscopy (AAS), from the Environmental Management Bureau Laboratory of DENR Region X. Sampling was done for two months, from August to September 2014 in a composite sampling. Samples were digested using START D Microwave Digestion System.

\subsection{Data analysis}

All results were expressed in terms of mean and standard deviation. Results were compared to available reference standards which include Philippine National Standard for Drinking Water of 2007, US Environmental Protection Agency of 2012 (PNSDW, 2007; US EPA, 2012), and the World Health Organization (WHO) drinking water quality guidelines. Data were further processed to roughly estimate risk analysis based on available standards. The Risk Quotient (RQ) was calculated as the ratio between the determined concentration and the available standard for $\mathrm{pH}$ and TDS. The calculated $\mathrm{RQ}$ of $>1$ may indicate potential environmental risk of the studied parameter (Galarpe and Parilla, 2014; WHO, 2008). Risk analysis for $\mathrm{Pb}$ and $\mathrm{Cd}$ were carried using the following equations (GEF/UNDP/IMO, 2004; Naveedullah et al., 2014):

$E x p_{\text {derm }}=C$ water $\times I R \times E F \times E D / B W \times A T$

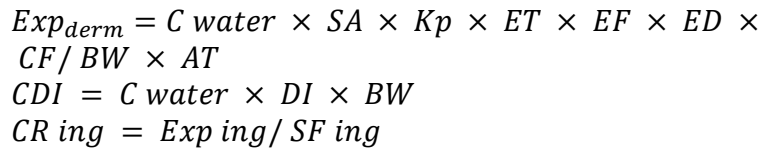

where Exp ing is the exposure dose through ingestion of water; Exp derm is the exposure dose through dermal absorption; CDI is the chronic daily intake; and $C R$ ing is the carcinogenic risk via ingestion route. Other variables are given in Table 1 (GEF/UNDP/IMO, 2004; Naveedullah et al., 2014).

Table 1: Parameters for estimating environmental risk assessment in this study

\begin{tabular}{|c|c|c|}
\hline Exposure factors & Unit & Value \\
\hline $\begin{array}{c}\text { Concentration of } \mathrm{Pb} \text { and } \mathrm{Cd} \text { in the } \\
\text { water sample ( } \mathrm{C} \text { water) }\end{array}$ & $\mu \mathrm{g} / \mathrm{L}$ & --- \\
\hline Water ingestion rate (IR) & L/day & 2.2 \\
\hline Exposure frequency(EF) & days/year & 360 \\
\hline Exposure duration (ED) & Year & 30 \\
\hline Average body weight (BW) & $\mathrm{Kg}$ & 70 \\
\hline Averaging time (AT) & Days & 10,950 \\
\hline Exposed skin area (SA) & $\mathrm{cm}^{2}$ & 28,000 \\
\hline Exposure time (ET) & h/day & 0.6 \\
\hline Unit conversion factor (CF) & $\mathrm{L} / \mathrm{cm}^{3}$ & 0.001 \\
\hline $\begin{array}{l}\text { Dermal permeability coefficient } \\
\text { (Kp) for Cd }\end{array}$ & $\mathrm{cm} / \mathrm{h}$ & 0.001 \\
\hline $\begin{array}{c}\text { Dermal permeability coefficient } \\
(\mathrm{Kp}) \text { for } \mathrm{Pb}\end{array}$ & $\mathrm{cm} / \mathrm{h}$ & 0.004 \\
\hline Average daily intake rate (DI) & L/day & 2.2 \\
\hline $\begin{array}{l}\text { Carcinogenic slope factor via } \\
\text { ingestion (SF ing) for Cd }\end{array}$ & $\mu \mathrm{g} / \mathrm{g} / \mathrm{d}^{-1}$ & $6.1 \times 10^{3}$ \\
\hline $\begin{array}{l}\text { Carcinogenic slope factor via } \\
\text { ingestion (SF ing) for } \mathrm{Pb}\end{array}$ & $\mu \mathrm{g} / \mathrm{g} / \mathrm{d}^{-1}$ & 8.5 \\
\hline
\end{tabular}

\section{Results and discussion}

\subsection{Physico-chemical analyses}

The physical properties evaluated for drinking water sources in USTP included temperature, $\mathrm{pH}$ and TDS. The chemical properties assessed were DO, alkalinity, salinity, and turbidity. Overall, temperature for all studied stations ranged from $26^{\circ} \mathrm{C}$ to $34^{\circ} \mathrm{C}$ (Fig. 1). The lowest temperature was detected in SC drinking water fountain while the highest temperature obtained was from IT faucet. On the other hand four of the studied stations showed slightly alkaline pH (ranged from 7.7 to 7.9) whereas the two other stations were more alkaline $(\mathrm{pH}$ ranged from 8.1 to 8.5 ) (Fig. 2). Water source from the engineering faucet had the highest $\mathrm{pH}$ measured. Overall, all studied stations had alkaline $\mathrm{pH}$ typical in communal drinking water sources (Koki et al., 2015). Similarly results of TDS analysis in all stations were within the maximum acceptable level is $500 \mathrm{mg} / \mathrm{L}$ in drinking water (Fig. 3). Determined alkalinity ranged from 259 to $292 \mathrm{mg} \mathrm{L}^{-1}$ (Fig. 4). The engineering faucet water source exhibited high alkalinity (325 $\mathrm{mg} \mathrm{L}^{-1}$ ) on August, 2014. The DO levels for the first five studied stations (faucets) ranged from 6.4 to 7.7 $\mathrm{mg} \mathrm{L}^{-1}$ (Fig. 5). The drinking fountain in the science center had the highest DO level (7.9 -8.6 $\mathrm{mg} \mathrm{L}^{-1}$ ). All stations were within the permissible limit for TDS $300 \mathrm{mg} \mathrm{L}^{-1}$ except for station 4 (Fig. 5). There was no turbidity for the water samples in USTP. No colloidal 
particles were also seen. All the water samples had no salinity.

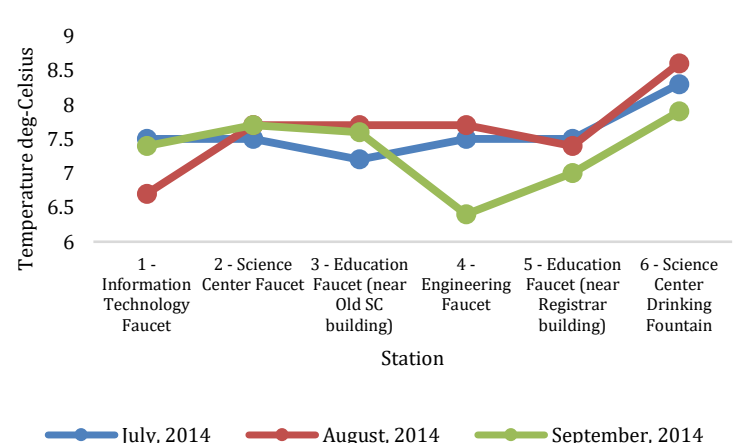

Fig. 1: Temperature levels of the different drinking water sources in USTP

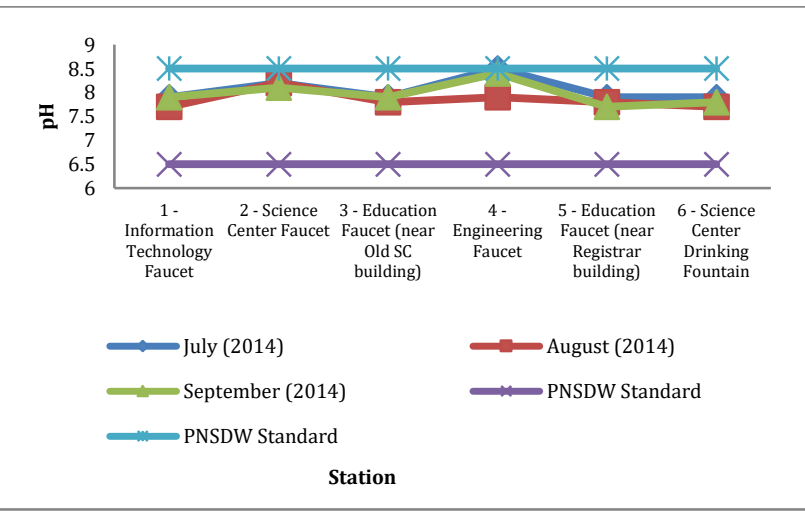

Fig. 2: pH levels of the different drinking water sources in USTP

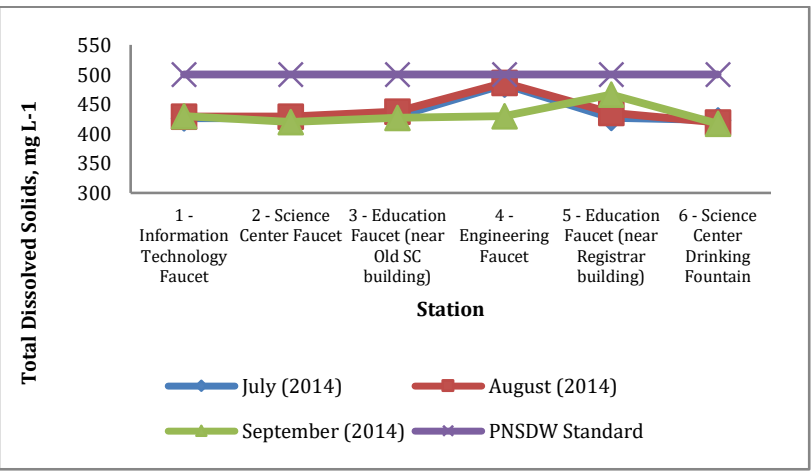

Fig. 3: TDS levels of the different drinking water sources in USTP

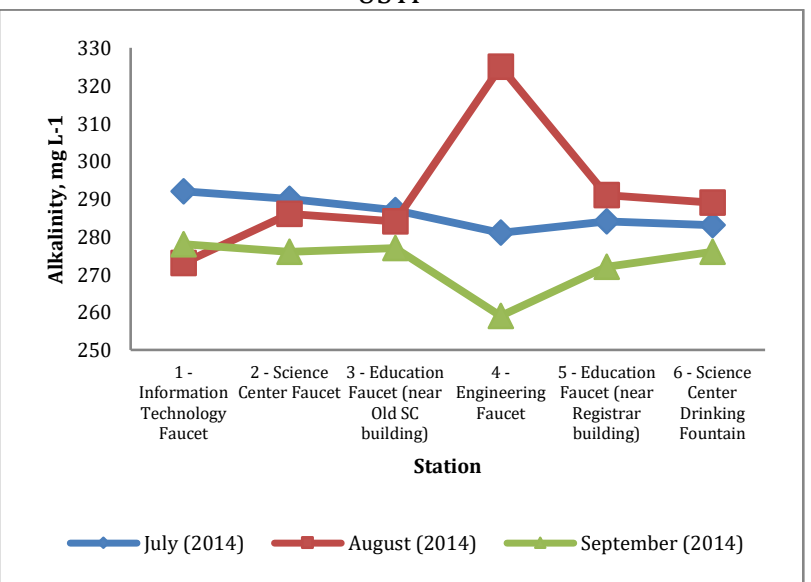

Fig. 4: Alkalinity levels of the different drinking water sources in USTP

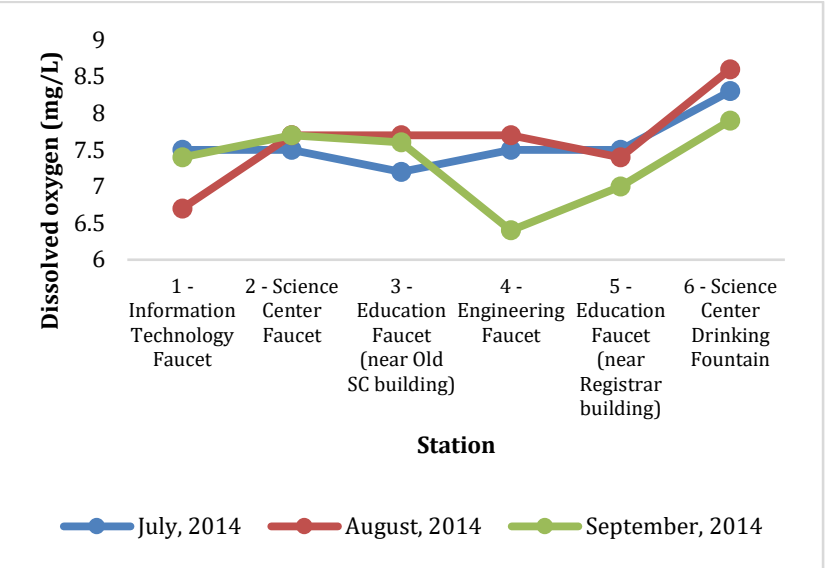

Fig. 5: Dissolved Oxygen levels of the different drinking water sources in USTP

\subsection{Heavy metals}

Fig. 6 presents the summary of results for total $\mathrm{Pb}$. The sample from the sceicne center faucet had the highest $\mathrm{Pb}$ concentration $(0.2865 \mathrm{ppm})$ whereas the lowest concentration $(0.1864 \mathrm{ppm})$ was from SC drinking fountain. Overall, regardless of studied stations (ranged from 0.1710-0.2930 ppm) all exceeded the limits set by PNSDW and USEPA. The Cd concentrations were also tested for all studied stations (Fig. 7). The determined Cd levels ranged from 0.1052 to $0.1806 \mathrm{ppm}$. Highest Cd concentration $(0.1560 \mathrm{ppm})$ was recorded in the science center faucet whereas the sample from the IT faucet had the lowest $\mathrm{Cd}$ concentration $(0.1254$ $\mathrm{ppm}$ ). The high levels of $\mathrm{Pb}$ and $\mathrm{Cb}$ can be associated to impurity or leaching of zinc galvanized pipes, lead fitting-solder pipes, cadmium-containing solders in fittings, water heaters, water coolers, and taps (Tonog and Poblete, 2015).

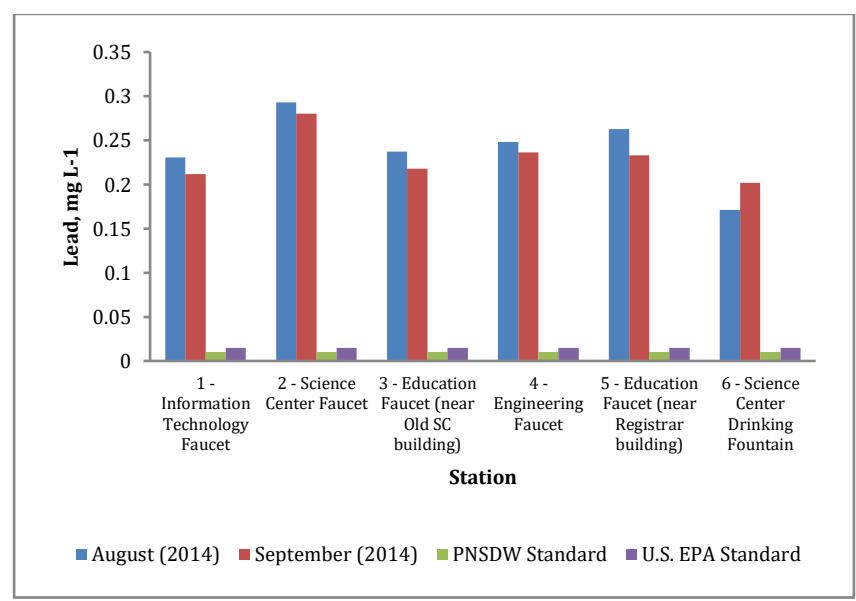

Fig. 6: Levels of Lead in different drinking water sources in USTP

\subsection{Risk assessment}

The RQ analysis for $\mathrm{pH}$ and TDS were based from the study of Galarpe and Parilla (2014). Two standards were used PNSDW and WHO. The RQ for both $\mathrm{pH}$ and TDS were approximately 1 (Table 2) indicating less to absence of risk in the water quality 
parameter. On the other hand, risk analysis of $\mathrm{Pb}$ and $\mathrm{Cd}$ were calculated based from the study of (GEF/UNDP/IMO, 2004; Naveedullah et al., 2014). Overall, Exp ing was found greater than Exp derm with $\mathrm{Pb}$ being higher than $\mathrm{Cd}$. The CDI for both metals were sparingly greater (mean values $\mathrm{Pb} 7.4329$ and Cd 4.422). Notably, the CR ing of both metals were beyond the tolerable or acceptable range which was $1.0 \times 10^{-6}$ to $1.0 \times 10^{-4}$ (GEF/UNDP/IMO, 2004). Thus, their is higher risk of developing cancer owing to exposure of a potential carcinogen in the water sample evidenced by elevated CR ing (Table 3 ).

\section{Conclusion}

All the results for the physico-chemical analyses of the different drinking water sources in USTP conforms to PNSDW, WHO, and US EPA water quality standards for $\mathrm{pH}$ and TDS. Other analyses do not show potential risk or contamination. However, results for $\mathrm{Pb}$ and $\mathrm{Cd}$ indicated contamination of the water sources also evidenced by high risk assessments of Exp ing, Exp derm, CR ing, and CDI. Both
$\mathrm{Cd}$ and $\mathrm{Pb}$ failed to meet the water quality standards. Overall, the results of the study were inconclusive owing to limited analyses considered in this study. Further monitoring is recommended.

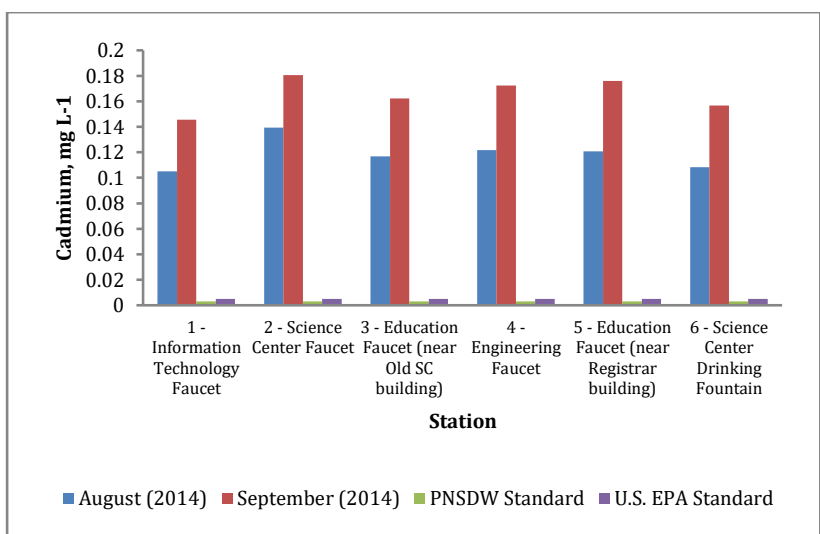

Fig. 7: Levels of Cadmium in different drinking water sources in USTP

Table 2: Risk quotient of selected physicochemical analyses

\begin{tabular}{|c|c|c|c|c|c|}
\hline \multirow{2}{*}{ Parameters } & \multirow{2}{*}{ This study } & \multicolumn{4}{|c|}{ Risk Analysis } \\
\hline & & PNSDW & $\mathrm{RQ}$ & WHO & $\mathrm{RQ}$ \\
\hline & 7.7-8.5 & $6.5-8.5$ & 1.1-1 & $7.0-8.5$ & 1.1-1 \\
\hline TDS (mg/L) & $420-485$ & 500 & $0.84-0.97$ & 500 & $0.84-0.97$ \\
\hline
\end{tabular}

Table 3: Risk analysis of the determined metals

\begin{tabular}{cccccc}
\hline \multirow{2}{*}{ Observation } & \multicolumn{3}{c}{ Metal concentration $(\mu \mathrm{g} / \mathrm{L})$} & \multicolumn{4}{c}{ Risk Analysis } \\
\cline { 2 - 5 } & $\mathrm{Pb}$ & Exp $_{\text {ing }}$ & Exp derm & CDI & $\mathrm{CR}_{\text {ing }}$ \\
\hline Max. & 286.5 & 8.8809 & 0.2713 & 9.0043 & 0.0015 \\
Min. & 186.5 & 5.7811 & 0.1766 & 5.8614 & 0.0009 \\
Mean & 236.5 & 7.331 & 0.2239 & 7.4329 & 0.0012 \\
SD & 70.7107 & 2.1919 & 0.067 & 2.2223 & 0.0004 \\
& $\mathrm{Cd}$ & & & & \\
Max. & 156 & 4.8357 & 0.0369 & 4.9029 & 0.5689 \\
Min. & 125.4 & 3.8872 & 0.0297 & 3.9411 & 0.4573 \\
Mean & 140.7 & 4.3614 & 0.0333 & 4.422 & 0.5131 \\
SD & 21.6375 & 0.6707 & 0.0051 & 0.68 & 0.0789 \\
\hline
\end{tabular}

\section{References}

APHA (1998). Standard methods for the examination of water and wastewater. American Public Health Association, Washington DC, USA.

EHSO (2014). What are the health effects of contaminants in drinking water?. Environment, Health and Safety Online, Available online at: http://www.ehso.com/ehshome/ DrWater/drinkingwatercontam.php.

Bensig EO, Maglangit FF, and Flores MJL (2014). Fecal and coliform levels as indicative factors in deterioration of the water quality of lahug river, Cebu City, Philippines. IAMURE International Journal of Ecology and Conservation, 10(1). Available online at: https://ejournals.ph/article.php?id=3052

Galarpe VRKR and Parilla RB (2014). Analysis of heavy metals in Cebu City Sanitary Landfill, Philippines. Journal of Environmental Science and Management, 17(1): 50-59.

GEF/UNDP/IMO (2004). Refined risk assessment technical report. Global Environment Facility/United Nations Development Programme/International Maritime Organization, Manila Bay Philippines: Environmental Management for the Seas of East Asia (PEMSEA), and Manila Bay Environmental Management Project (MBEMP), Technical Working Group for Refined Risk Assessment (TWG-RRA), Quezon City, Philippines.
Hernberg S (2000). Lead poisoning. American Journal of Industrial Medicine, 38(3): 244-254.

Jarup L (2003). Hazards of heavy metals contamination. Oxford Journals, 68(1): 167-182.

Koki IB, Bayero AS, Umar A, and Yusuf S (2015). Health risk assessment of heavy metals in water, air, soil and fish. African Journal of Pure and Applied Chemistry, 9(11): 204-210.

Lago RGM (2013). Water quality assessment of coastal waters of bayabas and bonbon in Cagayan de Oro City, Philippines. IAMURE International Journal of Marine Ecology, 1(1). Available online at: https://ejournals.ph/article.php?id=698

Naveedullah MZH, Yu C, Shen H, Duan D, Shen C, Lou L, and Chen Y (2014). Concentrations and human health risk assessment of selected heavy metals in surface water of the siling reservoir watershed in Zhejiang province, China. Polish Journal of Environmental Studies, 23(3): 801-811.

PNSDW (2007). Administrative Order No. 2007-012. Philippine National Standards for Drinking Water, Department of Health, Manila, Philippines. Available online at: www.doh.gov.ph.

Su GL (2008). Assessing the effect of a dumpsite to groundwater quality in Payatas, Philippines. American Journal of Environmental Sciences, 4(4): 262-266. 
Tonog MN and Poblete MM (2015). Drinking water quality assessment in selected barangays in Laoang, Northern Samar, Philippines. International Journal of Environmental Science and Development, 6(1): 29-33.

US EPA (2012). 2012 edition of the drinking water standards and health advisories. United States Environmental Protection Agency, USA. Available online at: https://www.epa.gov/ sites/production/files/2015-09/documents/dwstandards 2012.pdf
US EPA (2014). Lead in drinking water. United States Environmental Protection Agency, USA. Available online at: http://water.epa.gov/drink/info/lead.

WHO (2008). Guidelines for drinking-water quality. World Health Organization, Geneva, Switzerland. Available online at: http://www.who.int/water_sanitation_health/dwq/fulltext.p df 